\section{Frente al vacío cuerpos, espacios y gestos en el videoarte}

Gustavo Galuppo *

Resumen: El eje del texto se establecería en torno a una cierta idea del concepto de 'puesta en escena’ videográfica, en la cual el cuerpo y el espacio se relacionan de modos diversos, algunas veces esquivos, otras veces cercanos a su misma existencia como gestos vanos y sin consecuencias aparentes dentro de un relato posible ligado a la lógica de la causalidad. La idea es entonces establecer y desarrollar una reflexión en torno a esos modos expresivos del video, poniéndolos en relación con los modos de inscripción del cuerpo y el espacio en la imagen cinematográfica de la tradición narrativa.

Tradicionalmente, las formas cinematográficas dominantes establecen modos estandarizados de relacionar cuerpos y espacios según una lógica funcional que responde a una narración de sesgos clásicos. En el campo del video, por otra parte, la inscripción del cuerpo en el espacio mediante acciones se ha visto desligada de aquellas necesidades narrativas, por lo cual sus funciones se amplían en una búsqueda heterogénea que deja al espectador frente al desarrollo de gestos que muchas veces no responden más que a su propia existencia como tales. Gestos vanos. Acciones inútiles. Situaciones injustificadas. Cuerpos (humanos o animales) y espacios que establecen relaciones en una imagen que los priva de una claridad perfectamente funcional.

El presente trabajo tiene como objetivo poner en relación las formas expresivas del cine y el video relacionadas con ese tema puntual, poniendo énfasis en la relación que se establece entre el espectador y la obra. Desde un breve recorrido histórico por ambos medios que sirva para poner en perspectiva el eje abordado, el texto se focalizará en videastas argentinos contemporáneos cuya obra configura por sí misma una reflexión acerca de la puesta en relación del cuerpo, el espacio, y la mirada que los expresa.

Se abordarán entonces, poniéndolos en relación con otras obras históricas e internacionales, videos de Hernán Khourian, Andrés Denegri, Toia Bonino, y Javier Plano.

Palabras clave: cuerpo - espacio - espectador - obra - puesta en escena.

[Resúmenes en inglés y portugués en las páginas 47-48]

${ }^{(*)}$ Realiza video experimental desde 1998. Se desempeña también en el campo de la teoría cinematográfica, habiendo publicado numerosos textos en medios gráficos, publicaciones especializadas y libros colectivos. Desde 2004 se desempeña como docente universitario (Universidad Católica de Santa Fe, IUNA). 


\section{Introducción. Una cierta idea acerca de la puesta en escena cinematográfica}

Hay una aparición indefectible en (casi) toda imagen cinematográfica. Una rasgadura que se filtra por cada intersticio posible y se encarna plasmando sus coordenadas entre los límites del cuadro. El espacio, inevitable en la representación cinematográfica salvo en los casos en que este se avoca exclusivamente a los universos abstractos, se fija en la pantalla siempre, y con perseverancia lo hace hasta en su propia ausencia. Se desliza por los pliegues de la imagen (de los cuerpos, de los objetos) y se hace presente con obstinación, o deja el rastro de su ausencia cuando es negado brutalmente por un exceso en los recursos de estilización (la oscuridad absoluta, las abstracciones blancas de Carl T. Dreyer, la radical ausencia de imagen en Marguerite Duras, Joao Cesar Monteiro y Derek Jarman ${ }^{1}$ ). Pero aún allí, en ese preciso lugar en que es sometido a la privación de hacerse presente, la terquedad del espacio hace que se vislumbre su ausencia como elemento central de la imagen. Su desaparición estaría marcada por una necesidad arbitraria ajena a la misma imagen. Se trataría de un gesto evidente, de una manipulación, de un acto de prestidigitación exhibido como tal, enunciándose a sí mismo como voluntad negadora de lo evidente. Y en esa brutalización de la imagen, el espacio se yergue por sustracción. Si no está allí, si no es ofrecido entre los intersticios de cualquier cuerpo/objeto, es porque el principal acto en cuestión ha sido el de evitarlo, el de anularlo, el de sustraer su pura presencia a costa de enrarecer la imagen del mundo.

Pero es sabido, aún así, hecho presente, el espacio cinematográfico no vale sólo por su existencia entre los límites del cuadro. Vale, aún más, por su parte ausente, por lo negado en el recorte, por su reflejo imaginario en todo lo que desborda a su propia imagen. Si la cámara cercena el mundo del que se apropia, es justamente en ese gesto donde construye algo de su mayor potencia expresiva. Es sabido también, la imagen-cine no muestra, sino que oculta. $\mathrm{O}$ muestra apenas un fragmento pueril a costa de negar el universo entero. $\mathrm{Y}$ es esa su fuerza, su poder de sugestión. La embriaguez que suscita ante el misterio de la revelación negada o al menos diferida. De allí, de ese cercenamiento inevitable, sucede entonces que el espacio representado se multiplica en un vasto campo imaginario capaz de contener lo irrepresentable, lo que el cine no es ni nunca será capaz de alcanzar. Lo irrepresentable en el cine (el horror, el amor), puede encontrarse solamente allí donde su misma imagen le pone un límite preciso. Si esos límites son violados, si lo irrepresentable se encarna en el espacio de lo visible, deviene apenas en su reflejo estéril, su imagen opaca, empobrecida hasta la banalidad. El horror y el amor no son asunto de lo visible en la imagen-cine, pero sí de su precariedad, de su insuficiencia, de la imposibilidad de dar cuentas de ello y de la posibilidad de desenmarcarlos para mejor sugerirlos. Solamente su ausencia efectiva podría acercarse a una imagen posible.

El espacio del cine sería entonces el espacio entretejido entre lo representable y lo irrepresentable. Un espacio íntegramente imaginario constituido por lo visible y lo invisible, por lo palpable y lo sensible. Un espacio que, en el cine de la tradición narrativa, indefectiblemente enmarca cuerpos humanos sometidos al mismo régimen de exhibiciónocultamiento. Pero es allí que el cuerpo, a diferencia del espacio, puede ser contenido en su totalidad, o al menos un aspecto (una cara, una fase visible) de su totalidad; en él ya no es imprescindible ser sometido al cercenamiento. Y si en ese cine el indefectible espacio 
fílmico es necesario hasta la obligación, el cuerpo humano por él enmarcado es el rector, el eje, el centro de la mirada. De entre ellos, de sus interacciones, de sus fricciones y choques, de ese juego algo esquivo conocido como 'puesta en escena', emana la posibilidad de lo narrativo en el régimen del cine clásico y en sus reescrituras modernas y contemporáneas. Un cuerpo en la imagen, siempre, en su centro. Un cuerpo que gesticula, que camina, que corre, que se agita, que golpea, que recibe golpes, y que habla, sobre todo eso, un cuerpo hablante que sólo deja de hacerlo cuando resulta imprescindible ejecutar una acción operativa al relato. Un cuerpo funcional. Perfecta y meticulosamente funcional inventado por la imagen-cine (contemporánea al fordismo) para sostener el peso dramático de los grandes relatos.

El cine de la representación institucional jamás lo ha podido (ni lo podrá) evitar: pensar en la representación del cuerpo como eje fundamental de su desarrollo; en sus actitudes, sus acciones, sus gestos, sus palabras, y en sus afecciones y pensamientos puestos también en palabras. Aquella invención de ese cuerpo fordista, cuerpo funcional, absoluta e inevitablemente funcional, de la representación clásica, no representa, en cierta medida, sino la lógica de la producción. El cuerpo es un instrumento del relato perfecto, de un mecanismo que lo contiene, que lo acorrala y se cierne sobre él para mejor narrarlo. Ese cuerpo, para bien y para mal, debe tener una utilidad en la empresa firme de la lógica narrativa. Es casi un obrero del relato, de la ficción institucionalizada. Sus acciones y reacciones, y sus palabras asociadas, no pueden sino adscribirse a una estructura presa de una cierta fatalidad, de un destino determinado por el efecto de los géneros y por formas delimitadas en las exigencias sociopolíticas de los tiempos históricos.

Ese cuerpo, podría decirse, carece de libertad, y habita preso de un espacio que niega su propia existencia fantasmal, su parte ciega, su completud imaginaria, su potencia enraizada en el hecho de ser apenas una parte insignificante de un todo inaprensible. Cuerpo y espacio, allí, esbozan la idea de una hipervisibilidad en la que todo es expuesto a la luz de la conciencia-cine; ambos son estructurados entre sí por un relato que les otorga una completud imposible, o sólo posible a costa de la ilusión y el engaño. Pero es allí, en esa imposición, en ese límite y en esa imposibilidad, donde, nuevamente, el cine es capaz de reinventarse abriendo huecos, pequeñas brechas por las cuales se filtran destellos de inestabilidad. Allí, justo allí, traspasando esa línea delicada, corriéndose hacia ese otro régimen en el cual el gesto de la relación cuerpo-espacio se revela inoperante o improductivo, es donde estalla la potencia de lo insondable, la reserva de lo que rehúye a ser apresado y domesticado por la intriga.

Históricamente el cine ha ensayado esos desvíos, aún desde el interior mismo del cine clásico: Fritz Lang, Otto Preminger, Douglas Sirk, Joseph Mankiewicz, Alfred Hitchcock, Orson Welles, y la lista podría seguir ${ }^{2}$. Pero también desde fuera, desde una especie de periferia precursora de los grandes quiebres de la década del 60. Robert Bresson, Carl T. Dreyer, Yasujiro Ozu, y Roberto Rossellini, en distintos años y países, instauran juegos de puesta en escena en los que cuerpo y espacio se anudan de modos diversos para trascender la lógica del encadenamiento representativo mediante la ejecución de gestos ordinarios, a veces innecesarios, a veces desconectados del entorno que ya no los contiene. En ellos, o en sus películas, el cuerpo sigue obedeciendo a una especie de mandato externo sujeto a las intrigas, pero de un modo más lábil, sin responder del todo a esa lógica de la causa y el 
efecto, descarriándose ya con el impulso secreto de una banalidad cotidiana para superar su rol funcional. Allí, esos cuerpos se abandonan a la dispersión de la errancia seguidos en bloque por una cámara que los observa contemplar el espacio de una realidad que los supera (Rossellini), o mutan en afección pura al ser inscriptos en un espacio abstraído por el blanco pleno (Dreyer), o se avocan a una lucha entre la pureza narrativa de sus acciones y el impulso superador de un accionar inanimado (Bresson), o son finalmente diseccionados en sus gestos familiares cotidianos, en medio de la caída que supone habitar un espacio que cede a los cambios de una modernidad extranjerizante (Ozu).

Estos autores se convierten en referencia ineludible para (re) pensar los avatares de la puesta en escena después de la caída, esa metamorfosis producida tras la puesta en perspectiva del clasicismo cinematográfico por la emergencia de los Nuevos Cines surgidos durante la década del 60. Pero cabe preguntarse en este punto, ¿de qué hablamos al hablar de la puesta en escena en el cine? Tal concepto está sujeto a usos y abusos diversos, interpretaciones superficiales y confusiones diversas. Sin embargo, y pecando también de cierto reduccionismo arbitrario, no sería erróneo pensar en la puesta en escena desde la interacción de los cuerpos y el espacio construida por el dispositivo cinematográfico. Cuerpos y espacio. Acciones. Interacciones. Lo ya conocido. Pero nada allí (o muy poco al menos) quedaría de esa puesta en relación pensada originalmente para el teatro. El anudamiento entre los cuerpos y el espacio producidos por el cine no depende ya estrictamente de ellos y de sus evoluciones temporales, sino de las diversas configuraciones que pueden adoptar al ser asaltados en su existencia y violentados por la puesta en cuadro y por la puesta en sucesión. Cámara y montaje. Fragmentación y restitución. La parcialidad del espacio cinematográfico encuentra su afirmación o su negación en la cadena impuesta por el montaje. Es ahí donde el espacio se puede mostrar en su absoluta insuficiencia o, por el contrario, ensayar una completud dibujada en la mente del espectador por el montaje en continuidad. Y ahí también los cuerpos, que se anudan y desanudan de ese espacio parcelado para ser restituidos a una nueva organicidad. Puesta en escena cinematográfica, una puesta en relación de cuerpos, espacios y máquinas que ha transitado estadios diversos en las luchas por una cierta idea del realismo o por la realidad de la deconstrucción. El cine moderno ha ensayado muchas, disímiles y brutales. Los excesos pictórico-operísticos de Hans Syberberg, la radicalidad de los cuerpos desdramatizados por la palabra en Straub y Huillet, las voces sin cuerpo de Marguerite Duras, los cuerpos en bloque relacionándose siempre en las tablas de un escenario inexistente en Jacques Rivette, las fábulas de Miklos Jancsó en las que los cuerpos se sumergen en una coreografía excesiva y enrevesada, las múltiples operaciones de Godard, desde sus primeros años hasta la incorporación de la estética del video, la fragmentación y la discontinuidad absolutas en el zapping interminable del cine de Alexander Kluge, la indeterminación y la incertidumbre en las historias imposibles de Alain RobbeGrillet, los cuerpos y espacios múltiples diseminados en intrigas concéntricas y universos coexistentes de Raoul Ruiz, y hasta la exhibición descarnada de la caída de los cuerpos cotidianos en John Cassavetes y Maurice Pialat, y la misma caída pero en los cuerpos grises ensombrecidos por el fantasma omnipresente de la muerte y la derrota en Phillipe Garrel. No haría falta entonces reiterarlo, el cine moderno ha ensayado numerosas configuraciones de los posibles anudamientos entre cuerpos y espacios, tan numerosas como brutales. En estas formas, las emociones comunes de los cuerpos (y del espectador) se disuelven en 
otras no categorizables. Lo humano de la representación cede un poco ante la gracia del acto creativo, de la manipulación. Ya esos cuerpos no se acoplan al espacio en acciones reconocibles fuera del mismo cine. El tercer factor del tríptico cuerpo-espacio-máquina se impone sobre los otros, declara su rol rector en estos juegos de la puesta en escena.

\section{Una puesta en escena videográfica posible}

Ahora bien, teniendo en cuenta el derrotero histórico de los cuerpos y el espacio en la imagen-cine, ¿qué puede pensarse de lo mismo en el campo del llamado videoarte? En ese terreno, en principio, resulta algo evidente que el juego cambia un poco, que se corre de aquel territorio para explorar otras interacciones que no estarían sujetas a ningún tipo de encadenamiento de la lógica representativa propuesta por el cine en sus diversas formas. El video, dueño de particularidades intrínsecas emanadas por las mismas características de las máquinas en uso, asume de algún modo el desafío de generar otras relaciones cimentadas en las características procesuales de su medio y en los rasgos estéticos posibilitados por sus recursos tecnológicos. Pero aún así, aún teniendo en cuenta las particularidades del dispositivo-video y de sus evidentes y hasta insalvables consecuencias estéticas, no es menos cierto que el anudamiento del cuerpo y el espacio en todos los gestos posibles ha sido ensayado de maneras muy diversas por el cine; y el video, claro, no lo puede ignorar. En caso de hacerlo estaría jugando a inventar la rueda en pleno siglo XXI (y podría decirse... el videoarte ha inventado muchas ruedas ya en cincuenta años de existencia).

$\mathrm{Al}$ desentenderse en general el video de las estructuras narrativas clásicas, el anudamiento de cuerpos y espacios se revela consecuentemente en la formulación esporádica de gestos vanos, acciones inútiles sin otro destino que el de exhibirse como tales. Gestos esbozados al vacío. Acciones sin otra consecuencia que la de conformar o alterar la imagen con su misma presencia. La inutilidad, de algún modo, es el estigma de toda acción ejecutada entre los límites de la imagen-video, desmarcada ya de su pertenencia a una cadena de gestos claramente significantes en un contexto narrativo. Pero es justo esa aparente inutilidad, la que de algún modo arranca al cuerpo humano de la lógica funcional del cine clásico y de la lógica deconstructiva del cine moderno para devolverlo ya y definitivamente al terreno de la pura presencia. La imagen de un cuerpo, aquí, es eso, la imagen de un cuerpo y nada más eso. Ni siquiera sus acciones son ya capaces de otorgarle otro estatuto. Su discurrir en el espacio carece de destino, de función, de fin. Un hombre que camina en círculos en su estudio entre los límites del cuadro. Otro que realiza juegos simples con las manos y un libro. Otro que empuja juguetes a pilas forzándolos hasta agotar el límite de su vitalidad energética. Otro que registra con su cámara buscando una imagen imposible. Otro en una actitud cotidiana, mirando, hablando, accionando apenas el reflejo difuso de lo intrascendente. Y también los animales, humanizados para representar aquellos mismos gestos inútiles, sin consecuencias, y ya llevados por la descontextualización al punto más absurdo de la inutilidad perfecta.

La puesta en escena del video revela, en su paradójica trivialidad, las relaciones claras y conflictivas entre el cuerpo, el espacio y la máquina, ya que es justamente esa relación la que se pone en juego para volcar la mirada espectatorial sobre esa misma puesta en relación a través del gesto representado. Un gesto autorreferencial. En cierta medida, buscado 
a conciencia o no, el tríptico puesto en juego convierte a las relaciones que lo anudan como el eje de la obra en cuestión.

La relación establecida entonces en el video entre cuerpo, espacio y máquinas, se reconfigura en función de la especificidad técnica de este medio. Hay, de algún modo, una puesta en escena propiamente videográfica que anuda esos polos para lanzar gestos al vacío de la más absoluta indeterminación. Hablar, caminar, golpear, jugar; todo es válido, pero siempre y cuanto sea disfuncional en su pura ejecución desnuda. El video perfomático, cultivado tempranamente por Vito Acconci o Bruce Nauman, desvinculaba ya violentamente al cuerpo representado de aquella funcionalidad que se le otorgaba habitualmente en el cine narrativo, y lo ubicaba en un espacio cualquiera que se ha vuelto incapaz de actualizar acciones concretas y funcionales a un relato. Este cuerpo no es el cuerpo de la pose cotidiana, ni mucho menos es el cuerpo ordinario del cine narrativo clásico; no tiene pasado ni lineamientos psicológicos ni intriga que lo signifique. Este cuerpo en cambio se exhibe en un presente continuo que lo desliga de la historia y lo relaciona directamente con la mirada del espectador mediante su accionar vano; en ocasiones hasta lo interpela directamente mediante la mirada a cámara y la palabra (como en Acconci). Aquí, ese cuerpo, que es además el del mismo autor, es capaz de controlar sus propias evoluciones mientras se observa "en directo" en un circuito cerrado de video, y se expone crudamente sin otro motivo ni otra función más que la de ofrecerse a la mirada actuando, desprovisto de identidad, puro cuerpo abandonado a un tiempo continuo y extenuante, y enmarcado en un espacio cualquiera definido por los límites de un cuadro inmóvil y obsesivo dentro del cual opera generando relaciones banales (pasos rítmicos a través de un cuarto, recorridos geométricos). El cuerpo del video, aquí, es un territorio sobre el cual se puede operar (a veces violentamente) para desvincularlo de la funcionalidad ordinaria y convertirlo en objeto desnudo de la mirada propia y la ajena. Una pura actuación, pero actuación sin marco de referencia, sin relato que la incluya y la dramatice, una actuación cuyo único fin es trenzar el cuerpo y el espacio para ofrecer eso a la máquina casi como un tributo. En el video se establece un juego de relaciones disfuncionales, una puesta en escena anómala que, antes que 'narrar' un cuerpo en el marco de su historia, lo ubica (o se ubica) en un proceso de búsqueda constante, lo pone en situación para descubrir nuevas relaciones no funcionales entre cuerpo y espacio; entre el cuerpo, el espacio y las máquinas; y entre todo eso, el mismo autor, y el espectador. En el video argentino esa tendencia es abordada por diversos autores que exploran desde ángulos múltiples las posibilidades de esa puesta en escena videográfica. Desde la puesta en escena estrictamente autorreferencial, donde el propio autor es quien ejecuta acciones delante o detrás de la cámara (Hernán Khourian, Javier Plano, Gustavo Caprín ${ }^{3}$ ) hasta la concepción cercana al diario en video, como registro de lo ordinario en el entorno íntimo, cuerpos cercanos (al autor) ofrecidos en actitudes volátiles e insignificantes como testimonio del puro momento extraído del flujo temporal o narrativo (Andrés Denegri), y hasta la puesta en relación de cuerpos y espacios que evita directamente lo humano, poniendo en su lugar animales ahora humanizados por un gesto impuesto y destinado igualmente al fracaso (Toia Bonino).

Entre estas líneas estéticas, la presencia y la ausencia de los cuerpos en el espacio establece en su itinerario el derrotero de esas relaciones disfuncionales. La mirada espectatorial, frente a esta esquiva puesta en escena videográfica, es cercada por la imposibilidad de 
construir relaciones efectivas o utilitarias desde el orden de lo narrativo. La mirada es lanzada directamente al vacío, a la indeterminación, a lo inexplicado, a lo injustificado. La aparente insuficiencia de estas formas al anudar elementos en la imagen mediante acciones estériles es, justamente, su mayor reserva de potencia expresiva.

\section{Hernán Khourian y la imposibilidad de crear imágenes suficientes}

Entre las obras de estos autores argentinos, hay una en particular que podría pensarse casi como una declaración, el esbozo de un programa de trabajo que se (re) construye video a video. Esa obra es "Esplín o errar o sin embargo" (2007), de Hernán Khourian. En ella, el cuerpo y el espacio se anudan en una serie de acciones desconcertantes registradas por el ojo de una cámara-prótesis, dispositivo adherido al cuerpo del autor o, en algunos casos, transformada en mirada anómala dispuesta desde un objeto cualquiera. La inusual fisicalidad de la imagen emerge de la propagación del movimiento del cuerpo de quien filma hacia el aparato, y de allí a la imagen misma. Cuerpo, espacio y máquina se enmarañan en una entidad única en la que se redescubren las otras potencias de la puesta en escena del video. La imagen en la que se anuda aquel tríptico, se presenta como pura superficie de prueba y error en la que se inscriben objetos y acciones que desafían a la posible construcción de un sentido. Tres frutas sometidas a la búsqueda infructuosa de una composición pictórica. El polvo visibilizado por la luz. Un mapa. Una imagen del exterior transmitida por una cámara de vigilancia (la torre Eiffel). Esa misma imagen vista desde una ventana con el zoom digital de una cámara que exhibe su textura digital, su materia evanescente, su (in)materialidad. Una esfera navideña espejada. Una postal con la inscripción “¿Quién soy yo?” (en francés). Una mirada inhumana errática (casi animal, y de animal pequeño, como de ratón) que recorre la intrascendencia de lo distribuido sobre el piso (las patas de una mesa, unas botas, los zócalos). Y entre los objetos, las acciones inútiles, impensadas; la perfecta inutilidad de unos gestos lanzados al vacío de una búsqueda errática en apariencia sin sentido, sin más razón que la misma de ser expuestos para no comunicar nada, para obstruir la mirada del espectador, para desafiarlo o frustrarlo definitivamente. Nada hay (o al menos no parece haber), en esos gestos/acciones; nada más que su propia existencia destinada al fracaso o, en todo caso, a la negación absoluta de una justificación funcional dentro de un relato posible. Todo, aquí, parece ejecutarse para nada. Si hay relato, es el relato de una imposibilidad de construirlo, de otorgarle una unidad capaz de producir un sentido claro. Y lo curioso es que allí, justo allí, en esa falta, en esa aparente inoperancia de la puesta en escena, surge una 'otra cosa' capaz de hablar o interpelar más allá de su significación evidente, o sea, más allá de no decir nada. Pero es que en esta puesta en escena, o en esta puesta en situación espacio/temporal, las acciones banas revelan una especie de insatisfacción frente a la búsqueda de lo que no se conoce, lo que se ignora, y que por esa misma razón ni siquiera se puede buscar de modo efectivo. ¿Cómo buscar lo que no se sabe? ¿Dónde? No hay forma. Mover unas frutas construyendo una naturaleza muerta en mutación constante. Recorrer un mapa. Transitar nerviosamente el piso desde la mirada de un 'ratón'. Mirar una imagen. Construir otra similar. Jugar con postales que me interrogan irónicamente desde ese breve texto. Y romper con una violencia inesperada esa esfera 
reflejante en un gesto que, por sus características, se convierte de inmediato en un centro posible, un atisbo de algo sólido donde asirse por un instante; sólo un instante. Pero un instante que hace metástasis sobre el resto de las imágenes (las ya vistas y las que se verán). Lo que emerge con claridad en ese momento de ruptura (literalmente, ruptura de la esfera y ruptura en el video), es la imagen posible (o imposible, sería más acertado) de ese otro que intenta hablar video en primera persona. "Yo", quien enuncia, quien busca, quien mira y quien es mirado a la vez, quien se muestra y se oculta en un mismo gesto. "Yo", el otro; Khourian o quien sea, un ser inaccesible. Desconocido. Aquel que se pone en situación en ese espacio cerrado de su atelier jugando a mostrarse y ocultarse a través de acciones estériles, desarraigadas de este territorio del sentido claro y seguro, de la comodidad del espectador frente al relato cerrado. Y es que allí, en esa acción, en esa imagen, es la imagen del mismo realizador la que se ofrece reflejada sobre la esfera plateada. Y es su propia imagen la que se rompe en pedazos por efecto de su misma violencia. Y es su misma imagen después, la que manipulada por sus propias manos exhibidas en el juego con los pedazos de la esfera, la que revela esa incapacidad de ofrecer una imagen unitaria, válida, posible, suficiente. ¿Quién soy yo?, decía un texto borrado en la acumulación de acciones. Y en otro momento sus manos pintan de marrón/podrido la fruta que aún no se ha descompuesto, como tratando de forzar el tiempo. $Y$ en otro el espacio cerrado es recorrido vertiginosamente desde una mirada no humana sin encontrar nada relevante de lo que dar cuentas. $\mathrm{Y}$ en otro el exterior es referenciado mediante una imagen desnuda (la web o el zoom) o un mapa. Y en otro un viaje relámpago en subte nos devuelve al mismo interior sin habernos sacado nunca, como un violento y desconcertante efecto boomerang. Y todo en París, Francia, donde esta errancia absurda se configura en un espacio mínimo en el que parece imposible perderse, pero aún más, en el que parece imposible encontrarse. ¿Quién soy yo?, ¿o él? ¿Dónde y cómo buscarse o encontrarse?

En este video, las acciones que involucran cuerpos y espacios desde la máquina, pasan a asumir el grado de actuación pura en primera persona, desligada de cualquier circuito narrativo que le otorgue una significación más allá de su misma presencia, de la misma ejecución del gesto en cuestión. Y es esa puesta en escena, en su propia desnudez, la que pone en relación dos movimientos simultáneos entregados a un juego esquivo de cruces y desvíos, de nudos y alejamientos. El primero, el movimiento de la imagen misma puesta en marcha mediante las acciones, se niega a ser administrado desde la lógica del sentido y se entrega puramente como tal, como un movimiento que sólo responde al impulso de su existencia innecesaria, sin más exigencia que la de hacerse presente. El segundo, el movimiento mental suscitado en el espectador, es un movimiento tullido, una evolución que renguea en una búsqueda que se trunca permanentemente y deviene en errancia. Pero allí la puesta ensaya violentamente dos cruces posibles, dos nudos en los que ambos movimientos se rozan y generan una nueva perspectiva sobre el conjunto: la esfera reflejante que se quiebra con la imagen del autor y la postal con la leyenda “¿Quién soy yo?”. El cuerpo, el espacio, la máquina, y el autor, se entrelazan repentinamente y segregan un tercer movimiento que se presentará de modo intermitente, como una erupción esporádica que cambia las reglas del juego establecidas al comienzo y como un desafío apenas esbozado. Esta gestualidad maquinística es trabajada por Kohurian en gran parte de su obra. "Puna" (2006), de todos modos, es el video más cercano a la propuesta de "Esplín...”, aunque 
difiere un tanto de éste al ofrecer la posibilidad de visibilizar un objetivo, de atisvar en su transcurso la idea de que las acciones ahora se ponen marcha con un fin determinado. "Puna" se presenta entonces como la construcción en proceso permanente de una imagen posible de ese territorio demarcado por el mismo título. Y allí es donde se produce el desvío posible: frente a quien 'filma', hay un objeto determinado, reconocible, la Puna, lo cual pone en juego la posibilidad más clara de una intención. Si la sucesión de acciones articuladas mediante una imbricación profunda hombre-máquina-mirada no se alejan nunca de la evidente autorreferncialidad, el paisaje retratado y los ritos que en él se enmarcan asumen la posibilidad de otro destino para las imágenes. El juego de la puesta en escena es similar. El decurso de la prueba y el error. La exhibición del mismo proceso de búsqueda y construcción de una imagen. La interrogación de lo posible y lo imposible de esa imagen, la interrogación acerca de lo que es capaz de construirse en ella y a través de ella, de sus alcances y sus imposibilidades. De algún modo, en esta especie de díptico, se elabora una idea acerca de los límites de la representación audiovisual, del fracaso configurado en la imposibilidad de construir una imagen suficiente más allá del testimonio de la mirada propia mediatizada por las máquinas. Pero "Puna", aún así, contiene la evidencia del germen del gesto puesto en marcha, el trazo visible de un posible objetivo; allí, la Puna, se mantiene como centro de la imagen, conformándose en las variaciones audiovisuales a las que se ve sometida como el objeto excluyente de la mirada. Si las acciones ejecutadas se revelan vanas o infructuosas, lo hacen finalmente por la imposibilidad evidenciada de construir una imagen definitiva de ese paisaje. "Esplín...", al contrario, desnuda las acciones eliminando ese objeto de la representación. Una habitación cerrada no es la Puna, no configura en apariencia la justificación de esa búsqueda, y en ese corrimiento se convierte en el marco perfecto para una interrogación ahora lanzada a la indeterminación. Sólo el gesto, las acciones estériles; espacio, cuerpo, y cámara, anudados ahora desde una mirada que no deja de construirse en el vacío o frente a él.

\section{Javier Plano y el juego como acción insuficiente}

Ese anudamiento de la puesta en escena autorreferencial que traza el destino de gestos imprecisos, encuentra eco también en la obra de Javier Plano. "PMP" (siglas que refieren a portable media placer), de 2009, desarrolla en una única imagen sin cortes una curiosa operación de montaje ligada a la construcción descarnada de un simple mecanismo perfomático de enunciación. La imagen encuadra, sobre una mesa (aunque esa superficie podría ser también la del piso), un reproductor multimedia portátil apagado. En su visor se reflejan un ventilador de techo en funcionamiento y la lente de una cámara. Al cabo de pocos segundos una mano entra en cuadro y acciona el dispositivo para reproducir una ficción cinematográfica que transcurre en Corea. A partir de ese gesto inaugural, y durante los veinticinco minutos que dura el video, el encuadre permanecerá invariable y sin cortes, pero produciendo en su interior un montaje de imágenes a través del intercambio y la manipulación de diversos dispositivos reproductores portátiles que son sacados de cuadro para introducir uno nuevo con nuevas imágenes. El archivo que se va conformando en el proceso incluye extractos de cine, TV, publicidad gráfica, videojuegos, porno amateur, 
e informes institucionales; todo referido a la construcción de una imagen mediática del continente asiático. En el centro, partiendo la estructura en dos, "Hiroshima mon amour" (1959), de Alain Resnais y Marguerite Duras, establece el eje discursivo mediante aquel ya mítico diálogo entre los amantes:

- No has visto nada en Hiroshima. Nada.

- $\mathrm{Si}$, lo he visto en los noticieros...

Si bien el eje del discurso se establece aquí claramente en torno a esa configuración extranjerizante de una imagen de oriente plagada de estereotipos y lugares comunes releídos desde occidente, el hecho que hace virar esa disposición del material es la puesta en escena montada como un dispositivo perfomático, donde quien se encuentra tras la cámara interviene en el cuadro con sus manos visibilizadas intercambiando y accionando los reproductores para generar un montaje disfuncional. Un montaje que trastabilla en su propio accionar exhibido produciendo, en lugar de un nexo entre las imágenes diversas, una distancia insalvable cuyo abismo no llegan a llenar las manos que intercambian dispositivos a la vista y sin reparos. Dispositivos que, además, podemos intuir de fabricados en China. Este dispositivo montado por Javier Plano en "PNP", se extiende y se desvía posteriormente en otros de sus trabajos posteriores, replanteando aquel gesto inaugural de la puesta en escena perfomática para llevarla a un territorio en el que lo lúdico comienza a destituir toda posible lógica de las acciones presentadas. La idea del juego allí, entonces, irrumpe con cierto descaro patentizándose en acciones establecidas en el impreciso límite entre la ingenuidad y la perversidad. El deterioro, la destrucción, y la muerte, asoman anudados en puestas en escena que flirtean con el sinsentido y el fracaso como finalidad posible de los juegos. "Una pila de vida" (2010) es el que más claramente establece las coordenadas sobre las que se dispondrá este accionar. A diferencia del gesto construido por Khoruian, en el que el arrebato de cuerpo en sus temblores y su violencia transmitía una fisicalidad palpable a la cámara concebida por momentos como prótesis, Plano elige constituir siempre una especie de imagen que actúa como una subjetiva algo anómala. Anudamiento descentrado y frío entre su propia mirada y la cámara, que en su sequedad establece un punto desde el cual ambas comparten el campo visual, un campo casi inamovible, a medias humano y a medias maquinístico, en el que sus manos irrumpirán repetidamente para forzar el juego. $\mathrm{Y}$ es ese campo anómalo, distante y cercano, humano y tecnológico, el que contiene, en este caso, una serie de juguetes que serán sometidos al arduo trabajo del agotamiento, de la extinción de su propia vitalidad. El autor (y con él, el espectador) primero los observa en su funcionamiento básico: un jeep a control remoto, un tren musical, un avión, y una consola de juegos. Rápidamente esas acciones programadas y limitadas declaran toda su monotonía (el trencito musical pasa rápidamente de ser gracioso a ser absurdo, y finalmente intolerable), y con la progresiva intervención del autor que los fuerza continuamente a variar sus funciones y a seguir su curso, se comienza a percibir la finalidad de ese gesto, que no es otra más que la de forzar a esos juguetes a funcionar hasta agotar el último resto de la energía que los mueve. Hasta matarlos, se diría. No son entonces aquí las acciones realizadas las que se presentan como carentes de finalidad, sino que por el contrario es el mismo objetivo de éstas el que se desvincula de toda posible funcionalidad y de toda lógica operativa. Ago- 
tar entonces la vitalidad de los juguetes por el sólo hecho de observar (y hacer observar) el lento progreso del deterioro. Sólo eso, una especie de gesto infantil que evidencia su perversidad. El juego por el juego mismo, pero ahora desvirtuado, ya que el anudamiento cámara-cuerpo-juguetes revela la existencia de otra finalidad que rebasa lo simplemente lúdico del hecho. Ese juego algo perverso, aquí, no está sólo para ser jugado en la intimidad, sino para formar parte de una puesta en escena que se conforma en el proceso mismo, en un tiempo que se prolonga solamente para exhibir su progreso forzado hacia la extinción. El objetivo de las acciones se alcanza satisfactoriamente, como era de esperar, lo que ahora se torna frustrante y desestabilizador es la lógica misma del mecanismo puesto en marcha. Hay en los videos de Javier Plano una especie de violencia liberadora atemperada por el placer infantil de lo lúdico (o a la inversa, una ingenuidad infantil desvirtuada por una violencia punk). Una especie de ingenuidad anárquica, una vocación revulsiva, una actitud tan sutilmente destructiva como cargada de un humor salvajemente cáustico. En " 5 acciones (sobre la memoria colectiva)", también de 2010, pone en funcionamiento un dispositivo similar, pero aquí son las páginas arrancadas de libros escolares de historia argentina los que se ven sometidos a un maltrato obstinado en una serie de acciones diversas que ponen en perspectiva mediante el absurdo la funcionalidad de dichos textos. Finalmente, en "El proceso de duelo - Pulsión de muerte" (2012), video que parece conformar casi el cierre de la serie de los ya mencionados, realiza un movimiento dramáticamente inverso al de "Una pila de vida”. Aquí, el 'juguete’ en cuestión ya ha agotado su vitalidad, y desde allí se pone en funcionamiento una lógica inversa que devela ya claramente su absurda vocación destinada al fracaso. Las acciones exhibidas desde el dispositivo montado se declaran absolutamente insuficientes, vanas, grotescamente inútiles. Y es que se trata ahora del cadáver de una paloma sometido al trabajo infructuoso de volver a hacerla volar mediante el uso de cañitas voladoras atadas a sus alas. Desvinculando el gesto lúdico del puro juguete y enlazándolo ahora a un cuerpo muerto, el juego propuesto revela su otra intensidad solapada. Esa pulsión de muerte enunciada en el título, y que ya en los trabajos anteriores enturbiaba la falsa inocencia del juego infantil, en éste se hace patente de forma a la vez solemne e hilarante. Sobre el final, claro, se certificará lo ineficaz de la tarea emprendida. El pájaro muerto no volverá a volar. Y sólo quedará volarlo en pedazos con otro explosivo navideño para sellar la idea del fracaso. El niño, harto ya de fallar, rompe su juguete.

La puesta en escena ejercitada en estos videos patentiza entonces, en su aparente trivialidad, esas relaciones conflictivas entre el cuerpo, el espacio y la máquina, ya que es nuevamente esa relación hecha explícita la que se pone en juego como fin predominante del proceso creativo. Hacer y observarse haciendo en el proceso de prueba y error, en el progreso mismo de la construcción. Poner el cuerpo en relación al espacio y a la cámara en un gesto elocuentemente autorreferencial. En cierta medida, buscado a conciencia o no, el tríptico cuerpo (propio)-espacio-cámara puesto en juego convierte a las relaciones que lo anudan en el eje de la obra en cuestión. Pero si Hernán Khourian en su obra centra la idea del proceso exhibido en la imposibilidad de crear imágenes suficientes, Javier Plano se desliza hacia la construcción de acciones que se autodeclaran improductivas por el sólo hecho de que su objetivo parte de una concepción absurda, de una idea enarbolada como un proyecto perfectamente inútil. Los juguetes agotan su vitalidad energética, las páginas de los libros vuelan desde un edificio como papel picado; la paloma muerta, en cambio, no logra alzar vuelo, 
ahí la finalidad revela sus propios límites. De todas formas, que el objetivo planteado sea alcanzado o no, finalmente, se revela entonces como algo secundario. Lo que emerge con fuerza desde allí es la obstinación en llevar adelante acciones insuficientes motivadas por un puro placer infantil, salvaje y lúdico, pero también destinado irrevocablemente al fracaso. Un fracaso sellado con elocuencia cuando el pájaro muerto vuela en pedazos y parece cerrar allí esta serie de videos enraizados en la forma de lo lúdico como ejercicio perturbador.

\section{Toia Bonino y las fábulas improductivas}

A través de esa mirada en la que el animal pasa a ser el objeto de las acciones ejecutadas, es posible realizar un pequeño rodeo para establecer otro punto en el que esta idea de puesta en escena videográfica continúa cartografiando otros territorios posibles para el devenir de los cuerpos representados. Las ideas de lo anómalo, lo infructuoso, lo inútil, lo disfuncional, lo destinado al fracaso, parecen atravesar siempre estas formas supeditadas a un principio de indeterminación avocado a la frustración espectatorial. Si los cuerpos son expuestos en su accionar, ese mismo accionar se anuda con la cámara y el espacio en un juego algo opaco, en un proceso de búsqueda que no asume un rol claramente funcional dentro de algún tipo de estructura narrativa. Y también resulta evidente que, con cierta obstinación, todos estos trabajos plantean la fragmentación del espacio y el cercenamiento del cuerpo como principio estructural, como base en apariencia ineludible para la construcción de la imagen y el relato posible de lo indeterminado y lo incompleto. Si la totalidad no es aprehensible, tampoco lo será la parte. El desencuadre, en cierta medida, instituye desde la misma imagen esa idea de la incompletud y la insuficiencia. Y es que no sólo ya el espectador se enfrenta a sus límites, sino que la imagen misma declara su precariedad, su imposiblidad de formar parte de un todo coherente y cerrado más allá del mismo proceso de búsqueda y construcción autorreferencial al que se ve sometida.

En los videos de Toia Bonino, y volviendo tras el pequeño rodeo a la cuestión de los animales incluidos en la puesta en escena videográfica, se establece como principio la construcción algo desestabilizadora de fábulas disfuncionales. Fábulas sin moraleja, fábulas que eluden toda intencionalidad didáctica, pero que no abandonan su forma enunciativa primigenia en la que los animales son humanizados dentro de estilizados escenarios de sesgos fantásticos. Lo que se torna perturbador o frustrante en estos videos es, entonces, el propio hecho de que la forma familiar de la fábula sigue siendo perfectamente reconocible, pero no así su intención moralizadora. En cierto sentido aún hay fábula, pero en otro, claramente no pueda haberla.

Las fábulas improductivas de Bonino se construyen alrededor de los especímenes de las granjas articulando con brutalidad un relato sobre la delicadeza plástica y la violencia primitiva. La fábula de la gallina, del cordero, del cerdo, y de la vaca. Cuatro fábulas insuficientes en las que los personajes se niegan a ser humanizados para establecer el pertinente discurso didáctico. Si el gesto humano es impuesto por la fuerza, se revela siempre mayor la potencia animal que no reconoce el lugar de las expectativas humanas puestas en juego por el gesto. Y esa otra potencia suscitada es siempre destructiva (sólo en términos humanos, claro está), una potencia avasallante que genera un doble movimiento de líneas 
paralelas: la ceremonia de los rituales humanos, por un lado, y por el otro, el puro instinto animal que desconoce y subvierte tales arbitrariedades del rito social puesto en escena. El doble movimiento de estas líneas produce, inevitablemente, la posibilidad o la idea de un cruce, de una intersección, y ese punto de choque no es otro más que el terreno de litigio de lo absurdo propuesto, de lo imposible, el territorio esquivo en el que la fábula estalla y se autodeclara evidentemente defectuosa, absolutamente improcedente. Pero aún así, aún concibiendo la contradictoria posibilidad de la existencia paradójica de una fábula sin moraleja, ese doble movimiento también instituye otro plano significante en el que lo humano y lo animal, en su imposible convergencia desde lo pautado socialmente, esbozan la permanencia del infructuoso gesto inaugural en la relatividad de la violencia exhibida; que ya se presenta tanto como simple expresión del instinto animal y a la vez, desde la perspectiva humana, como brutalidad injustificada.

Estos procedimientos se evidencian ya en "Jauría" (2008), el primero de la serie, donde la fragmentación excesiva y la idea de la parte por el todo como forma dominante de la imagen dejan entrever primero la incomodidad suscitada por la dificultad en el reconocimiento de las acciones, ubicando además inicialmente al espectador en el rol de voyeur, dejándolo espiar apenas a través de unos orificios indiscernibles. El detalle algo descentrado y el ambiente sonoro se articulan, sin embargo, estableciendo el entorno claro de un gallinero. Nada demasiado significativo. El relato posible se suspende en una observación enrarecida por el predominio del fragmento y por el balbuceo del montaje. Pero es allí que el conflicto se suscita cuando se evidencia una arbitraria intervención humana en ese universo animal. A las gallinas se le arrojan unas flores mientras picotean todo lo que se encuentra en el piso. Luego, y ya dejando ver las manos (de la autora) que intervienen en el desarrollo, se arrojan unas bolitas. Allí el relato se enrarece. Sobre la contemplación del accionar animal se acopla la intencionalidad opaca de una acción humana cuyo objetivo no parece ser otro que la misma intervención. Tras la posterior muerte de una de las gallinas, la fábula improductiva se desliza violentamente hacia otros territorios. El cadáver, ya desplumado y desangrado, se deja sobre el piso para, primero, rodearlo de flores en un incongruente gesto fúnebre, y para después dibujar su silueta como se hace en las escenas de los crímenes. Desde allí, desde esa irrupción desestabilizadora de la significación humana en ese universo animal sin códigos morales, la muerte adquiere otros sentidos y ese límite entre el instinto y la brutalidad se desdibuja para teñir el gesto animal de un peso más que humano. El cuerpo de la gallina muerta, finalmente, será devorado por las otras gallinas (la jauría, casi una plaga zombie, una horda caníbal) en una situación que se deja invadir por un tono incómodamente brutal. Así, la forma de la fábula humaniza a estos animales, pero la intención se suspende anulando la posibilidad de la moraleja, activando en cambio el mecanismo de una mirada espectatorial que trastabilla frente a la convergencia de intenciones contradictorias imposibles de anudar en un único gesto.

En "Festividad" (2009), son dos corderos los que se ven sometidos a una infructuosa humanización cuando se los insta a participar de una celebración absurda. Los animales intentan comerse los bonetes y rechazan la fruta servida con anárquica serenidad, nada reconocen en estos elementos que los haga formar parte del rito propuesto. "El jardín de las delicias" (2010) retoma esa idea para desarrollarla en otras líneas. Aquí el espacio de la fábula es el chiquero y los personajes unos cerdos. Desde la referencia a la obra de El 
Bosco pone en perspectiva los conceptos del pecado, el placer y la muerte estableciendo nuevamente ese terreno de litigio entre el rito humano y el instinto animal.

La puesta en escena ensayada en estos videos establece primero un conjunto balbuceante mediante la exacerbación de la fragmentación del espacio y de los cuerpos y, también con cierta recurrencia, mediante la separación de las imágenes en breves interrupciones en negro que parecen negar al montaje como una operación capaz de restituir una unidad totalizadora. La mirada puesta allí en juego, descentrada y atenta al detalle arrancado de su entorno, se vuelve después sobre sí misma cuando exhibe directamente las acciones humanas que intervienen el universo animal; unas manos que entran en cuadro para forzar del algún modo la situación mediante gestos sencillos como incluir nuevos materiales en la escena. Si bien esos universos se encuentran ya alterados desde la construcción de una escenografía que incluye elementos extraños, la irrupción del gesto que fuerza la situación redirecciona la propuesta hacia la imposición infructuosa de un simbolismo ajeno a la vida animal; un ejercicio simbólico negado por los mismos animales, en una clara e involuntaria oposición a la determinación humana.

En estos videos de Toia Bonino se construye una puesta en escena anómala, híbrida. Subyacen siempre una especie de teatralidad desarticulada y un vuelo cinematográfico velado. Los actores se niegan a participar del teatro propuesto, y la articulación del cine no alcanza para restituir la unidad del relato posible. Lo que queda, entonces, es la acción obstinada de quien compone la puesta en escena para trascender ambos medios enunciando, en una primera persona algo sesgada, lo infructuoso de su determinación. La idea del fracaso, nuevamente, se erige como un acto trascendente que pone en perspectiva los deseos y las frustraciones del espectador enfrentado a un acto discordante, absurdo, y tan delicadamente bello como brutalmente violento.

En "Deshoras" (2012), la teatralidad de la puesta se disuelve en un gesto contemplativo mucho más despojado, en el cuál se afirma con más fuerza esa mirada autorreferencial declarada en el anudamiento del cuerpo, el espacio, y la cámara-ojo autodeclarada. Aquí ya no hay fábula posible, sólo el intento de elaborar dos puntos de vista incongruentes, humano y animal, que convergen finalmente enfrentados en el ojo de la vaca que llora, exhibiendo el reflejo difuso de la autora en el mismo acto del registro.

\section{Andrés Denegri y la fugacidad del gesto cotidiano}

La obra de Denegri escapa un tanto a los lineamientos desarrollados en los videos de los artistas precedentes en su relación con la puesta en escena de acciones autorreferenciales. Sin embargo, su concepción de la imagen-video, atraviesa unas coordenadas de un orden conceptual aledaño, diverso pero a la vez cercano. Aún contemplando la diferencia entre sus distintas obras, es la puesta en escena de la mirada, y con ella de quien mira, lo que se establece como eje principal y como foco de interés.

En "III Momentos" (1998) se espían a través del zoom de una cámara de video las acciones cotidianas de quienes habitan un edificio cercano. La exposición descarnada de la intimidad ajena y la textura de la imagen rota por el zoom digital excesivo, redireccionan sin embargo el interés de lo observado hacia el rol de quien observa. No se trata tanto aquí del hecho de 
exhibir lo íntimo ajeno, sino en cambio de poner en relieve la actitud de quien viola esa intimidad. La mirada propia es el eje, desmontar esa mirada frente al espectador y producir una especie de transferencia en el rol de voyeur. Lo observado, en última instancia, es secundario. "Grito", de 2006, es el que más se enlaza con aquella idea del anudamiento cuerpo-espaciocámara mediante la puesta en escena de acciones autorreferenciales. Aquí a lo que se asiste, es al presente de la revisión de un pasado familiar. El gesto, en cierto sentido, es paralelo al de "III Momentos". No es entonces ese pasado familiar el centro absoluto y excluyente de la puesta, sino en cambio la actitud de quien intenta procesarlo revisando home movies y generando alteraciones en esas imágenes de la memoria familiar. Lo que vemos, aunque sutilmente velado en un fuera de campo casi permanente, es al mismo autor accionando el dispositivo de proyección. Rearmando el entramado de las imágenes en el mismo proceso de reconstrucción de la memoria y de construcción del video. ${ }^{4}$

Hay, sin embargo, un giro interesante en su propuesta que comienza a establecer otros parámetros para la enunciación de esa mirada plenamente subjetiva concebida como base de la imagen creada. El giro, aunque anunciado en videos anteriores, se da más clara y rotundamente con "Colonia" (2008), un breve video de dos minutos y medio que deja establecidas las pautas para desarrollos posteriores de una técnica particular aplicada a un tema preciso: la secuencia fotográfica puesta en movimiento como un intento poéticamente infructuoso de aferrar la fugacidad de los vitales gestos cotidianos. En este caso, una situación mínima, intrascendente, apenas alguien que observa el río. La imagen tartamudea en un movimiento tullido que nunca llega a concretarse con fluidez, exhibiendo en cambio un medio camino entre la inmovilidad de la fotografía y el falso movimiento del video. La foto, como en Roland Barthes, parece intentar capturar y retener ese instante vivido, pero para que ese momento se pueda restituir con algo de su intensidad primigenia, es necesario paradójicamente que el video la deje pasar y torne infructuosa su intención. El instante se hace evidentemente fugitivo, y el gesto improductivo de quien intenta vanamente retenerlo revela allí toda su poética contradicción. No será posible retenerlo, claro, pero allí mismo, entre las grietas de esa imposibilidad, es que asomarán a veces relumbrones de una 'verdad' generalmente oculta. Una verdad improbable patentizada en la sensibilidad esquiva de un gesto ordinario o en una palabra impensada.

"Llueve en Mar del Plata" (2011) asume ya con desprejuicio y radicalidad esa propuesta. Si en "Colonia" no estaba del todo clara la pertenencia del autor al momento observado más allá de su misma mirada, en este declara con intensidad la pertenencia a un espacio construido desde la adscripción al entorno afectivo más cercano. Y es que se trata de eso, apenas de eso. Una colección de momentos vividos entre amigos. Situaciones cotidianas y en apariencia absolutamente intrascendentes. Diálogos pasajeros. Risas. Una lluvia que se oye pero nunca se ve. Unos paisajes marítimos. Y esa lucha entre la foto y el video, entre lo fijo y lo móvil, balbuceando en ese mismo movimiento anómalo la melancolía de la pérdida y la alegría de la recuperación. Y allí, en esa puesta en valor de lo íntimo y lo pasajero, se abren esas brechas fugaces por las que se asoma violentamente el estallido sensible de lo cotidiano. Algunas veces una imagen, de esas que se detienen en una pose fugaz pero que al mismo tiempo son absorbidas y borradas por el movimiento. Otras veces una palabra, esa palabra que en el momento puede haber pasado como una expresión aleatoria o vacía, pero que adquiere en este contexto la relevancia del gesto revelador. "Llueve al revés", se 
oye decir por una voz femenina, y lo absurdo de tal afirmación revela de un golpe certero el valor sensible del más ordinario de todos los gestos.

Posteriormente a "Llueve en Mar del Plata", Denegri comienza a desarrollar un proyecto junto a Gustavo Caprín: “This is just to say”. Se trata básicamente de una correspondencia semanal entre ambos videastas. Videocartas que van estableciendo un diálogo posible entre Argentina y España, desde la perspectiva de la intimidad, la confesión, la fraternidad, y el comentario irónico. Andrés Denegri, en sus videocartas, trabaja fundamentalmente sobre la línea de los videos mencionados. Aunque prescinde en muchos casos del recurso de las secuencias de fotos, el eje sigue siendo el intento de eternizar lo sensible del momento cotidiano experimentado en el entorno afectivo.

Si bien esta idea desarrollada por Denegri parece alejarse un tanto de lo planteado por Khourian, Plano, y Bonino, comulga sin embargo en el gesto inaugural que la sostiene y le da sentido. No son aquí sus acciones puestas en imagen las que intervienen el espacio (no se verán, como en los anteriores, sus manos interviniendo la puesta para construirla en ese proceso), sino que en cambio su gesto autorreferencial, su acción puesta en juego, es la de observar y participar desde esa mirada sensible. Observar y poner en escena entonces lo banal, lo infraordinario, el cotidiano intrascendente, todos esos aconteceres que oficialmente no son dignos de convertirse en imagen más allá del archivo personal. Observar y tratar infructuosamente de capturar lo evanescente, de retener la fugacidad del instante en un gesto tan sensiblemente romántico como improcedente.

Esta imagen pone ahora en escena cuerpos en actitudes cotidianas, pero los articula con la mirada de quien es testigo y partícipe; y allí anuda de un modo íntimo y particular esos polos del cuerpo, el espacio, y la cámara. Y es aquí, nuevamente, en este gesto destinado al fracaso, en esta intención improductiva de retener lo que inevitablemente se esfuma, donde emerge una 'otra cosa', una aparición furtiva del afecto que pone en duda la imposibilidad de la empresa abordada.

\section{La perfecta inutilidad de nuestros actos}

Estos autores establecen en sus propuestas las nuevas coordenadas de un territorio muchas veces frecuentado por el video. La puesta en escena videográfica, concebida como un puro gesto perfomático, como una actuación escindida de funcionalidad, ha sido una de las bases históricas de este medio y una de las formas expresivas que más ha recorrido desde múltiples ángulos. Sin embargo, la conciencia que emerge en estas obras señaladas, es una conciencia autorreflexiva que no se desentiende de ciertos conceptos cinematográficos, aunque sea ya para trascenderlos, trastocarlos o subvertirlos. Una conciencia que, mediante un obstinado movimiento, pone en marcha un mecanismo anómalo capaz de desnudar la insuficiencia misma de la imagen. Su incompletud. Sus límites. Sus imposibilidades. Sus deseos truncos. Sus búsquedas desatinadas. Sus fracasos. La inutilidad de estas acciones lanzadas al vacío esboza finalmente su perfección en el fracaso mismo. Allí radica su potencia algo velada. En la articulación de cuerpo, espacio, y cámara en una puesta en escena evidentemente improductiva que no deja, sin embargo, de plantearse como una interrogación perturbadora a las miradas puestas en juego. 
Tal vez, finalmente, no sea necesario remarcarlo. Esa imagen suficiente no se alcanzará jamás. Ese juego se revelará finalmente absurdo. Esa fábula se topará con su insuficiencia. Esos afectos del cotidiano no serán restituidos. Lo que prima entonces, más allá de estos fracasos memorables, es el gesto bellamente desatinado de intentarlo a sabiendas. El gesto profundo que, en un mismo movimiento, construye una experiencia estética desde la imposibilidad y suscita una conciencia sobre los límites mismos de la representación audiovisual.

\section{Notas}

1. En "El hombre atlántico", Marguerite Duras deja la pantalla en negro durante los últimos minutos para dar paso a la voz (y a su imagen sonora) en su plenitud. Derek Jarman, en su última película, "Blue", compone una pantalla azul sobre la que se inscribe la banda sonora de sus última etapa de vida, afectado ya por el SIDA y padeciendo de ceguera (una ceguera en azul). Y Joa Cesar Monteiro realiza una curiosa versión de "Blancanieves" sin imagen, que sólo aparece en flashes a modo de interludios, dejando que los actores reciten sus partes frente el objetivo tapado de la cámara

2. Alfred Hitchcock y Orson Welles marcarían de algún modo una especie de conciencia del límite del modelo clásico y su transformación en el moderno. Mankiewicz y Sirk, la previa puesta al límite de recursos y estilo clásicos que, en sus películas, devienen en exceso de forma y estructura. Y Lang y Preminger, de otro modo y entre otros, encarnan la perfección de un modelo y el punto álgido de uno de sus principales géneros, el policial negro. Cabe destacar que, en esta lista arbitraria, sólo uno de estos directores es norteamericano, el resto, los que llegan a la perfección y a la superación de una forma puramente 'americana', son europeos emigrados

3. Gustavo Caprín es un realizador argentino radicado en España, sus videos están realizados allí. La expresión 'video argentino’ es utilizada aquí como una generalización. Más correcto en este caso sería: 'videos realizados por artistas argentinos', lo cuál implicaría un recorte por demás de caprichoso e injustificado. Me quedo entonces con la idea del video argentino, como una generalización incorrecta pero útil para este grupo de videastas que comparten su raíz y ciertos rasgos estéticos. De todos modos, por cuestiones de espacio, la obra de Caprín no será abordada en este texto; pero cabe destacarla por su importancia en estas líneas de trabajo examinadas

4. En ese mismo sentido puede verse también “Diario de Pamplona”, de Gonzalo Egurza, un video planteado con una puesta en escena autorreferencial similar, pero que lleva el entramado hacia un terreno cercano al de una ficción fantasmagórica.

Summary: The article focuses on the concept of "video work staging", in which the body and the space are related in various ways, sometimes elusive, sometimes close to their very existence as empty gestures without apparent consequences within a possible story linked to the logic of causality. The idea is then to establish and develop a reflection on those expressive video modes, relating them to the registration modes of the body and the space in the cinematic image of the narrative tradition. 
Traditionally dominant film formats establish standardized ways of linking bodies and spaces according to a functional logic that responds to a classic biases narration. In the field of video, on the other hand, the inscription of the body in space through actions has been detached from those narrative needs, so their functions are expanded in a heterogeneous search that faces the spectator to a variety of gestures that often only responds to his own existence. Empty gestures. Useless actions. Unjustified situations. Bodies (human or animal) and spaces that establish relations within an image that deprives them of a perfectly functional clarity.

This work aims to relate the expressive ways of film and video related to that specific topic, emphasizing the relationship established between the spectator and the work. From a brief historical survey of both media that serves to put into perspective the addressed axis, the text will focus on contemporary argentine videographers whose work sets itself a reflection on the linking of body, space, and the look involved. They will be related to other international works and Khourian Hernán, Andrés Denegri, Toia Bonino and Javier Plano videos.

Keywords: body - Space - spectator - staging - work.

Resumo: O eixo deste trabalho se estabelece em torno a certa idéia do conceito de posta em cena videográfica, na qual o corpo e o espaço se relacionam de modos diversos, algumas vezes esquivos, outras vezes pertos a sua mesma existência como gestos vãos e sem conseqüências aparentes dentro dum relato ligado à lógica da causalidade. A idéia é então estabelecer e desenvolver uma reflexão ao redor a esses modos expressivos do vídeo, relacionando-os com os modos de inscrição do corpo e do espaço na imagem cinematográfica da tradição narrativa.

Tradicionalmente, as formas cinematográficas dominantes estabelecem modos estandardizados de relacionar corpos e espaços segundo uma lógica funcional que responde a uma narração de características clássicas. No campo do vídeo, por outra parte, a inscrição do corpo no espaço mediante ações se viu desligada de aquelas necessidades narrativas, por o qual suas funções se ampliam numa procura heterogênea que deixa ao espectador frente ao desenvolvimento de gestos que muitas vezes não respondem mais que a sua própria existência como tais. Gestos vãos. Ações inúteis. Situações injustificadas. Corpos (humanos ou animais) e espaços que estabelecem relações uma imagem que os priva de uma claridade perfeitamente funcional.

Este trabalho tem como objetivo relacionar as formas expressivas do cinema e o vídeo relacionados como esse tema pontual, pondo o ênfase na relação que se estabelece entre o espectador e a obra. Desde um percurso histórico por ambos meios que serva para por em perspectiva o eixo abordado, o texto se focalizará em videastas argentinos contemporâneos cuia obra configura por se mesma uma reflexão sobre a posta em relação do corpo, o espaço e a mirada que os expressa.

Se abordarão, então, em relação com outras obras históricas e internacionais, vídeos de Hernán Khourian, Andrés Denegri, Toia Bonino, e Javier Plano.

Palabras chave: corpo - espaço - espectador - obra - posto em cena. 